\section{The Relationship between Health Locus of Control and Quality of Life in Patients with Chronic Low Back Pain}

\section{Kronik Bel Ağrılı Hastalarda Sağlık Denetim Odağı ve Yașam Kalitesi Arasındaki İlișki}

\begin{abstract}
AIM: To investigate the relationship between health locus of control and quality of life in patients with chronic low back pain.

MATERIAL and METHODS: Pain intensity by visual analog scale, quality of life related to health by the World Health Organization Quality of Life (WHOQOL) assessment and disability level by Turkish version of Oswestry Disability Index (ODI) were evaluated. Multidimensional Health Locus of Control (MHLC) for the perception to responsibility and control of the individual over his/her own health was used.
\end{abstract}

RESULTS: Patients were separated into two groups according to the scores of ODI as group with Low Disability [0-40 minimal/moderate disability; $n=53$ ] and group with High Disability [40-100 severe disability / crippled/bedbound/exaggerating; $n=60]$. Scores of chance health locus of control (CHLC) in the subscale of MHLC were significantly higher in the patients who had high disability $(\mathrm{p}<0.05)$. Negative correlation between CHLC scores and all domains of WHOQOL, positive correlation between CHLC scores and disability level and pain severity was found $(\mathrm{p}<0.05)$.

CONCLUSION: Quality of life was negatively influenced in the patients with low back pain who had chance health locus of control. LOC is an important parameter in evaluation and treatment of patients with LBP.

KEYWORDS: Low back pain, Locus of control, Quality of life

\section{ÖZ}

AMAÇ: Çalışmamız, Kronik Bel Ağrılı (KBA) hastalarda sağlık denetim odağı ve yaşam kalitesi arasındaki ilişkiyi incelemek amacıyla planlanmıştır.

YÖNTEM ve GEREÇ: Ağrı şiddeti görsel analog skalası ile genel sağlıkla ilgili yaşam kalitesi; Dünya Sağlık Örgütü Yaşam Kalitesi Ölçeği Türkçe Sürümü-kısa form (WHOQOL) anketi ile fonksiyonel yetersizlik düzeyi ise bel ağrılı hastalarda Türk populasyonu için geçerliliği güvenilirliği saptanmış olan Oswestry Yetersizlik Indeksi (ODI) ile değerlendirildi. Çok Yönlü Sağlık Denetim Odağı Anketi (MHLC) ile bireylerin sağlıkları üzerindeki sorumluluk ve denetim algısını ölçüldü.

BULGULAR: Hastalar, ODI puanlarına göre minimal özürlü [0-40 minimal/orta özür; n=53] veya şiddetli özürlü [40-100 ciddi özür; n=60] olarak iki gruba ayrıldı. Şiddetli özürlü hastaların MHLC anketinin alt başlığı olan "şans / kaderci denetim odağı" puanları anlamlı olarak yüksekti. "şans/kaderci denetim odağ1" puanları ile yaşam kalitesinin tüm parametreleri arasında negatif yönde, özürlülük düzeyi ve ağrı şiddeti arasında ise pozitif yönde anlamlı korelasyonlar bulundu $(\mathrm{p}<0.05)$.

SONUÇ: Kronik bel ağrılı hastalarda şans ya da kaderci denetim odağı algısının yüksek olması yaşam kalitesini olumsuz yönde etkilemektedir. Sağlık denetim odağı bel ağrılı hastaların değerlendirmesinde ve tedavisinde önemli bir parametredir.

ANAHTAR SÖZCÜKLER: Bel ağrısı, Sağlık denetim odağı, Yaşam kalitesi

\section{Yesim SENGUL ${ }^{1}$ \\ Bilge KARA $^{2}$ \\ M. Nuri ARDA ${ }^{3}$}

1,2 Dokuz Eylul University, School of Physical Therapy and Rehabilitation, Izmir, Turkey

3 Dokuz Eylul University, School of Medicine, Neurosurgery Department, Izmir, Turkey

Received : 28.01.2009

Accepted : 06.11.2009

Correspondence address: Yesim SENGUL

Phone : +90 2324124939

E-mail : yesim.salik@deu.edu.tr 


\section{INTRODUCTION}

Health of locus (HLOC) is one of the most frequently investigated psychosocial factors in patients with low back pain (LBP) $(17,5,12)$. HLOC, which is defined as the perceived control of the individual's own health (11), was found by Wallston et al. (22) and is frequently used for patients with low back pain $(5,8)$. Perceived control is associated with personal control for positive psychological results (16). HLOC involves internal (individuals perceive events to be more under their own control), external (other individuals such as physicians and family play a large part in determining on their own health) or chance factors (individuals believe that their health is influenced by chance or luck) (22). Consequently, locus of control (LOC) or the belief that LBP relief is determined by personal factors, chance, or health care professionals, has been found to be related to with higher levels of LBP-related disability $(8,5)$. Locus of control is important in improving the quality of life and prognoses of patients with LBP. Each subscale is identified between different countries and cultures $(13,17)$.

Although a number of studies in different cultures and populations have investigated disability in patients with LBP, we found no literature data on the relationship between HLOC and quality of life in Turkish patients with LBP.

The objective of the present study was to investigate the relationship between health locus of control and quality of life in Turkish patients with chronic low back pain.

\section{MATERIALS and METHODS}

\section{Patients:}

One hundred and thirteen patients with chronic low back pain (male: 41 , female: 72 ) were included in the present study. Individuals who agreed to participate were referred to the Neurosurgery Department of Dokuz Eylul University School of Medicine. All patients had chronic low back pain (CLBP) lasting longer than 3 months and none had undergone spinal surgery. Severe negative consequences for physical and/or mental functioning (i.e., psychiatric disease, neurological problem) were excluded.

\section{Measures:}

The demographic characteristics of the subjects were recorded as gender, age, and body mass index (weight / height $\mathrm{x}$ height). Pain, health locus of control, disability and quality of life were assessed.

\section{Pain}

A Visual Analogue Scale (VAS), consisting of a horizontal $100 \mathrm{~mm}$ line, with the words 'no pain' at one end and 'worst imaginable pain' at the other end was used for assessing current pain intensity in low back pain. The levels of pain both at rest and during activity were measured (7).

\section{Disability}

The Oswestry Low Back Pain Disability Index (ODI) is a disease-specific measure of disability among patients with LBP. This questionnaire has been used extensively in randomized trials and has shown reliability and validity in Turkish patients with Low Back Pain (19). On this scale, 0-20 equates to minimal disability, 20-40 moderate disability, 40-60 severe disability, $60-80$ crippled, and $80-100$ bed-bound or exaggerating (3).

\section{Locus of control}

HLOC was measured by the Multidimensional Health Locus of Control (MHLC) questionnaire. The questionnaire contains 18 items on beliefs about responsibility for health, with a six-point Likert-type scale ranging from "strongly disagree" to "strongly agree". Three subscales of the questionnaire include internal health locus of control (IHLC: individuals perceive events to be more under their own control), external health locus of control (EHLC: other individuals such as health professional and family play a large part in determining on their own health), and chance health locus of control (CHLC: individuals believe that their health influenced by chance or luck). Each subscale is composed of six items and the scores are summed with a possible range of for each subscale of between 6 and 36 . Higher scores indicate greater belief in each subscale domains in terms of control over health (22).

\section{Quality of life}

Quality of life related to general health was evaluated through Turkish version of World Health Organization Quality of Life Scale-Brief Form [WHOQL BREF-100]. This scale has 4 subdomains as Physical Health Domain, Psychological Health Domain, Social Relationships Domain and Environmental Domain. Higher points indicate a better quality of life (4). Patients were informed as 
required, and their consent was obtained for assessments.

\section{Statistical Analysis}

Descriptive statistics included the frequency distribution for categorical variables (gender, disability level), and the mean and standard deviation for continuous variables (age, body mass index and disability) (Table 1). Statistical analyses of data were obtained by "SPSS for Windows Ver 11.0" software. Comparisons between two independent groups were performed with the unpaired Student's t-test. Pearson's Correlation Coefficient was calculated to examine the association between pain severity, disability, quality of life and LOC-related variables. The statistical significance level was chosen as a $\mathrm{p}$ value less than 0.05 .

\section{RESULTS}

113 patients (41 male, 72 female) who accepted to participate were recruited in the current study. Demographic and clinical data of the study group are shown in Table 1.

The patients were separated into two groups according to the ODI scores, a group with Low Disability [0-40 minimal/moderate disability; $\mathrm{n}=53$ ] and a group with High Disability [40-100

Table I: Demographic Characteristics of Patients with Chronic Low Back Pain.

\begin{tabular}{|l|c|c|}
\hline & $\mathrm{n}$ & $\%$ \\
\hline Gender & & \\
Female & 72 & 63.7 \\
Male & 41 & 36.3 \\
\hline Level of ODI & & \\
Minimal disability & 17 & 15.0 \\
Moderate disability & 36 & 31.9 \\
Severe Disability & 31 & 27.4 \\
Crippled & 22 & 19.5 \\
Bed-bound/Exaggerating & 7 & 6.2 \\
\hline & \multicolumn{2}{|c|}{$\mathrm{X} \pm \mathrm{Sd}$} \\
\hline${ }^{* *}$ ODI & $44.84 \pm 21.99$ \\
\hline Age & \multicolumn{2}{|c|}{$45.06 \pm 15.45$} \\
\hline${ }^{*}$ BMI kg/m2 & $27.99 \pm 6.96$ \\
\hline
\end{tabular}

${ }^{*}$ BMI: Body Mass Index

${ }^{* *}$ ODI: Oswestry Disability Index severe/crippled/bed-bound or exaggerating; $\mathrm{n}=60]$ ). The number of LBP patients with minimal and moderate disability was half of the study group. Data were analyzed in two groups (Group 1: patients with Low Disability, Group 2: patients with high disability) to determine accurate statistic accounting because of the small sample size of the patients with minimal disability $(\mathrm{n}=17)$ (Table 1$)$.

Pain level at rest was the same in both groups $(p>0.05)$. Pain level at activity was significantly higher in the group with high disability than in the group with low disability $(\mathrm{p}<0.05)$ (Table 2$)$.

Subscales of MHLC, internal and external factors, were not significantly different between the groups $(p>0.05)$. Scores of CHLC in the subscale of MHLC were significantly higher in patients with high disability $(\mathrm{p}<0.05)$ (Table 2).

All of the WHOQOL questionnaire scores and ODI scores were significantly different in CLBP patients with low and high disability $(\mathrm{p}<0.05)$. Group 2 was found to have low scores in subscales of WHOQOL (Physical Health Domain, Psychological Health Domain, Social Relationships Domain and Environmental Domain) $(\mathrm{p}<0.05)$ (Table 2).

The relationship between subscales of MHLC and quality of life, disability level, pain intensity at activity and rest of the study group is shown in Table 3. A significant relationship was found between IHLC and pain intensity at activity $(\mathrm{r}=.28 ; \mathrm{p}<0.01)$, physical health domain of WHOQOL and disability level $(\mathrm{r}=-.19, .23 ; \mathrm{p}<0.05)$. There was no correlation between EHLC and all variables except for pain severity at rest $(\mathrm{r}=.27 ; \mathrm{p}<0.05)$. A statistically significant relationship existed between CHLC and all domains of WHOQOL ([r=-.40 -.44, -.26, -.34; $\mathrm{p}<0.01)$, pain severity at rest and activity $(\mathrm{r}=.26, .36$; $\mathrm{p}<0.01)$ and disability level $(\mathrm{r}=.45 ; \mathrm{p}<0.01)$ (Table 3$)$.

\section{DISCUSSION}

The present study investigated the relationship between HLOC and quality of life in patients with CLBP. Chronic pain, behavioral and physical impairment and psychological distress affect the level of disability related to LBP (21). Besides, it is suggested that disability may impair psychosocial and cognitive functions (9). The present study results were interpreted for two groups according to the scores of ODI, a group with low disability and a group with high disability. In addition, the 
Table II: Results of Health Locus of Control and Quality of Life According to Disability Level of the Study Group

\begin{tabular}{|c|c|c|c|}
\hline & $\begin{array}{c}\text { Group 1 } \\
(\mathrm{n}=53) \\
\mathrm{X} \pm \mathrm{Sd}\end{array}$ & $\begin{array}{c}\text { Group 2 } \\
(\mathrm{n}=60) \\
\mathrm{X} \pm \mathrm{Sd}\end{array}$ & $\mathbf{p}^{*}$ \\
\hline Pain Severity (VAS) & & & \\
\hline Rest & $42.69 \pm 25.29$ & $82.17 \pm 27.93$ & 0.06 \\
\hline Activity & $68.46 \pm 18.93$ & & 0.01 \\
\hline Health Locus of Control (HLC) & & $26.67 \pm 6.70$ & 0.12 \\
\hline Internal health locus of control & $24.47 \pm 8.00$ & $23.87 \pm 5.56$ & 0.10 \\
\hline External health locus of control & $22.04 \pm 6.15$ & $19.50 \pm 8.81$ & 0.01 \\
\hline Chance health locus of control & $12.98 \pm 6.66$ & & \\
\hline WHOQOL & & $40.00 \pm 17.53$ & 0.01 \\
\hline Physical Health & $59.51 \pm 14.61$ & $50.26 \pm 19.04$ & 0.01 \\
\hline Psychological Health & $69.89 \pm 12.20$ & $60.10 \pm 22.27$ & 0.01 \\
\hline Social Relationships & $70.44 \pm 16.55$ & $50.95 \pm 17.50$ & 0.01 \\
\hline Environmental & $62.56 \pm 14.29$ & $61.70 \pm 14.92$ & 0.01 \\
\hline ODI & $25.76 \pm 9.49$ & & \\
\hline
\end{tabular}

Group 1: Group with Low Disability: Minimal / Moderate Disability

Group 2: Group with High Disability: Severe/Crippled/Exaggerating Disability

${ }^{*} \mathbf{p}<0.05$ Student's t test, WHOQOL: World Health Organization Quality of Life Scale,

ODI: Oswestry Disability Index

Table III: Correlation Between Health Locus of Control and Quality of Life, Disability Level, Pain Intensity of the Study Group

\begin{tabular}{|l|c|c|c|}
\hline & $\begin{array}{c}\text { Internal health locus of } \\
\text { control } \\
\text { Pearson's r }\end{array}$ & $\begin{array}{c}\text { External health locus of } \\
\text { control } \\
\text { Pearson's r }\end{array}$ & $\begin{array}{c}\text { Chance health locus of } \\
\text { control } \\
\text { Pearson's r }\end{array}$ \\
\hline Pain Severity (VAS) & -0.07 & $0.27^{* *}$ & $0.26^{* *}$ \\
\hline Rest & $0.28^{* *}$ & 0.11 & $0.36^{* *}$ \\
\hline Activity & & & $-0.40^{* *}$ \\
\hline WHOQOL & $-0.19^{*}$ & -0.14 & $-0.44^{* *}$ \\
\hline Physical Health & 0.09 & -0.07 & $-0.26^{* *}$ \\
\hline Psychological Health & -0.13 & 0.07 & $-0.34^{* *}$ \\
\hline Social Relationships & -0.03 & 0.08 & $0.45^{* *}$ \\
\hline Environmental & $0.23^{*}$ & 0.15 & \\
\hline ODI & 0 & & \\
\hline
\end{tabular}

${ }^{*} \mathbf{p}<0.05,{ }^{* *} \mathrm{p}<0.01$. WHOQOL: World Health Organization Quality of Life Scale,

ODI: Oswestry Disability Index 
correlation between HLOC and quality of life in LBP was investigated, and a relation was found between HLOC and quality of life, disability and pain intensity.

In the current study, pain level at rest and activity were measured in CLBP patients with low and high disability. The results of this study suggested that pain severity at rest was the same in both patient groups with low and high disability. However, patients with high disability had increased pain severity during activity.

HLOC is one of the most commonly used parameters of health belief in recent years and is measured by MHLC. This questionnaire, containing of three subscales (internal, external, and chance factors), has been used for investigating psychosocial factors in the development and persistence of low back pain $(12,18,1,8)$. The parameters of this questionnaire are generally the degree of the individual's belief that his or her behavior is controlled by external or internal factors. The term "external" refers to those individuals who believe happenings in their lives are due to factors such as physicians, therapist, chance and luck. Higher EHLC indicates that the patient is participates less in treatment decisions. Having higher EHLC increases the susceptibility to depression due to producing feelings of helplessness, and it negatively affects the prognosis of LBP $(5,8)$. IHLC means that patients participate in treatment decisions, and a synergy exists between the therapist and the patients $(1,6)$. IHLC is positively accompanied with knowledge and attitude while belief in external factors is accompanied with negative health behaviors and weak psychological state (15). Individuals who have higher CHLC bear fatalistic beliefs, and believe in fate regarding health and illness (22). The literature indicates that CHLC plays a considerable role in transition from acute to chronic pain and design of treatment in CLBP $(8,2)$. Similar to all other studies, the present paper suggested that CHLC was related with high pain severity, increased disability level and decreased quality of life in patients with chronic LBP. This relation between LOC and disability level and quality of life showed that the CLBP patients may be separated into groups according to their HLOC at the beginning of physiotherapy.
Mackenbach and et al. suggested that chronically ill persons who believe in external factors such as chance and health professionals were more susceptible to disability (14). Haldorsen et al. suggested that patients with low back pain who had IHLC had low levels of disability after treatment when compared to patients with EHLC (5). Kovacs et al. suggested that there was a correlation between severity of pain, degree of disability and quality of life (10). Recently, it was demonstrated in the literature that evolution of chronic LBP (transition from acute to chronic LBP) is related with functional (quality of life, duration of sickness) and emotional factors (anxiety, depression, negative beliefs) $(8,9,20)$. It is suggested that emotional and functional factors play a major role in treatment decisions of $\operatorname{LBP}(2,8)$. We investigated the correlation between health LOC and quality of life in LBP and found a relation between HLOC and quality of life, disability and pain intensity. Negative beliefs (such as chance, luck, health professionals and family playing a large part in determining their own health) decreased quality of life in patients with CLBP. Outcomes of ignored LOC reveal beliefs about the patient's own health and these beliefs influence the prognosis and success of LBP treatment. Engström et al. found that patients who believed external factors had lower exercise frequency among all the patients referred to the physiotherapy clinics (2). We would like to emphasize that internal, external, and chance factors affect treatment processes and evolution of LBP because of the effects on the quality of life and disability level. Moreover, education on anatomy, pain, physical and mental coping strategies, work, lifestyle, back school, exercise and cognitivebehavioral treatment may be used for CLBP patients who have chance and external LOC.

In conclusion, the current study findings associated with chance LOC with all subscales of WHOQL support the previous results. We believe that high scores of chance LOC accompany increased disability levels, decreased quality of life and increased pain severity in Turkish patients with LBP. HLOC, which measures the belief of patients regarding their own health, plays an important role in evaluation and treatment of patients with LBP. 


\section{REFERENCES}

1. Braman AC, Goméz RG. Patient personality predicts preference for relationships with doctors. Personality and Individual Differences 37: 815-826, 2004.

2. Engström LO, Oberg B. Patient adherence in an individualized rehabilitation programme: a clinical followup.Scand J Public Health. 33(1):11-8, 2005.

3. Fairbank JC, Couper J, Davies JB, O'Brien JP: The Oswestry low back pain disability questionnaire. Physiotherapy 66:271-273, 1980 .

4. Fidaner H, Elbi H, Fidaner C, Eser SY, Eser E, Göker E: Psychometric properties of WHOQOL-100 and WHOQOLBref. Psychiatr Psychol Psychopharmacol 7(2): 23-40, 1999.

5. Haldorsen EM, Indahl A, Ursin H. Patients with low back pain not returning to work: a 12-month follow-up study. Behavior Medicine 23: 1202-1207, 1998.

6. Hashimoto H, Fukuhara S. The influence of control on preferences for information and decision making. Patient Education and Counselling 55: 236-240, 2004.

7. Jensen MP, Karoly P: Self-report scales and procedures for assessing pain in adults. In: Turk DC, Melzack R, Handbook of Pain Assessment. The Guilford, New York Pres, 1992: 135-151.

8. Koleck M, Mazaux JM, Rascl N, Schweiter MB. Psycho-social factors and coping strategies as predictors of chronic evolution and quality of life in patients with low back pain: a prospective study. Eur J Pain 10(1): 1-11, 2006.

9. Kovacs FM, Abraira V, Zamora J, Fernández C; Spanish Back Pain Research Network. The transition from acute to subacute and chronic low back pain: a study based on determinants of quality of life and prediction of chronic disability. Spine 30(15):1786-92, 2005.

10. Kovacs FM, Abraira V, Zamora J, Teresa Gil del Real M, Llobera J, Fernández C, Bauza JR, Bauza K, Coll J, Cuadri M, Duro E, Gili J, Gestoso M, Gómez M, González J, Ibañez P, Jover A, Lázaro P, Llinás M, Mateu C, Mufraggi N, Muriel A, Nicolau C, Olivera MA, Pascual P, Perelló L, Pozo F, Revuelta T, Reyes V, Ribot S, Ripoll J, Ripoll J, Rodríguez E; KovacsAtención Primaria Group. Correlation betweenpain, disability, and quality of life in patients with common low back pain. Spine 15;29(2):206-10, 2004.
11. Laffrey SC, Isenberg M. The relationship of internal locus of control, value placed on health, perceived importance of exercise, and participation in physical activity during leisure. International Journal of Nursing Studies 40: 453-459, 2003.

12. Linton SJ. A review of psychological risk factors in back and neck pain. Spine 25: 1148-1156, 2000.

13. Luszczynsk A, Schwarzer R. Multidimensional health locus of control: comments on the construct and its measurement. Journal of Health Psychology 10: 633-641, 2005.

14. Mackenbach JP, Borsboom GJJM, Nusselder W J, Looman CWN, Schrijvers CTM. Determinants of levels and changes of physical functioning in chronically ill persons: results from the GLOBE Study. J Epidemiol Community Health 55;631-638, 2001.

15. Malcarne VL, Drahota A, Hamilton NA: Children's healthrelated locus of control beliefs: ethnicity, gender, and family income.Child Health Care 34:47-59, 2005.

16. Martin, CR, Jomeen J. The impact of clinical management type on maternal locus of control in pregnant women with prelabour rupture of membranes at term. Health Psychology Update 13: 3- 13, 2004.

17. Oliveira VC, Furiati T, Sakamoto A, Ferreira P. Health locus of control questionnaire for patients with chronic low back pain: psychometric properties of the Brazilian-Portuguese version Physiother. Res. Int. 13(1): 42-52, 2008.

18. Takakura M, Sakihara S. Psychosocial correlates of depressive symptoms among Japanese high school students. Journal of Adolescent Health 28: 82-89, 2001.

19. Yakut E, Düger T, Oksüz C, Yörükan S, Ureten K, Turan D, Frat T, Kiraz S, Krd N, Kayhan H, Yakut Y, Güler C.Validation of the Turkish version of the Oswestry Disability Index for patients with low back pain. Spine 29(5):581-5, 2004.

20. Waddell G. The back pain revolution. London: Elsevier Limited, 2004.

21. Waddell G, Newton M, Henderson I, Somerville D, Main CJ. A fear-avoidance beliefs questionnaire (FABQ) and the role of fear-avoidance beliefs in chronic low back pain and disability. Pain 52 (2):157-168, 1993.

22. Wallston KA, Wallston BS, Devillus R. Development of the multidimensional health locus of control scales (MHLC). Health Education Monographs 6: 160-170, 1978. 